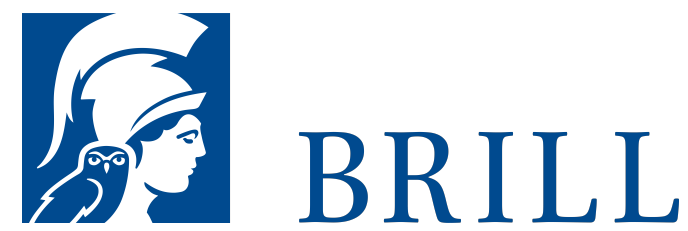

\title{
Aristokratische oder demokratische Gerechtigkeit?
}

Die politische Philosophie des Aristoteles und Martha Nussbaums egalitaristische Rezeption

Author: Manuel Knoll

Im zeitgenössischen Denken hat die politische Philosophie des Aristoteles eine beachtliche Renaissance erfahren. Dabei wurde Aristoteles zumeist als Vordenker der demokratischen Gleichheit und der egalitären Gerechtigkeit verstanden. Diese Auffassung wird heute auch pointiert von Martha Nussbaum, einer führenden Intellektuellen der USA, vertreten. Das Buch zeigt, warum diese Interpretationen unangemessen sind und gibt eine Deutung, die den politischen Grundüberzeugungen des Aristoteles gerecht wird. Aristoteles erweist sich als politischer Denker, der von der fundamentalen Ungleichheit der Menschen ausgeht und die gerechte politische Ordnung als eine Aristokratie der moralisch und intellektuell Tüchtigsten begreift. Manuel Knoll präsentiert nicht bloß eine ideengeschichtliche Studie, sondern reflektiert auch problemorientiert über die Aktualität des Aristoteles. Dabei konfrontiert er dessen aristokratische politische Philosophie mit Martha Nussbaums „Fähigkeiten-Ethik“ und mit anderen Positionen des zeitgenössischen Egalitarismus. So gelangt seine Untersuchung zu dem Resultat, dass seit der Antike bis heute zwei gegensätzliche und unvereinbare Grundpositionen zur politischen Gerechtigkeit existieren.

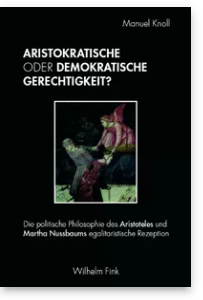

Pages: 325

Seiten

Language:

German

Subjects: Social \& Political

Philosophy, Philosophy

Publisher: Brill | Fink

E-Book (PDF)

Released online:

o2 Dec 2019

ISBN: 978-3-

8467-4858-9

List price

USD $\$ 63.00$

Paperback

Publication date: 16 Sep 2009

ISBN: 978-37705-4858-3

List price

USD \$63.00 
For more information see brill.com

Order information: Order online at brill.com +44330 333 0049 | customerservices@brill.com Submission information: brill.com/authors

Titles published by Brill | Fink, Brill | mentis or Brill | Schöningh: +49(o)715413279216| brill@brocom.de 